\title{
The Syntactic Errors on Verbs Usage in Essay Writing by Students of Mahasaraswati Denpasar
}

\author{
Ni Komang Putri Widari ${ }^{1}$, I Nengah Sudipa ${ }^{2}$, Ni Ketut Widiarchani Matradewi ${ }^{3} *$ \\ putriwidari44@gmail.com \\ Udayana University, Denpasar, Indonesia
}

\begin{abstract}
This study aims to find out the types of errors and to analyze the syntactic errors committed by third semester students of English Education Study Program at Mahasaraswati University Denpasar. This study is classified into qualitative research design. To analyze the data, theory types of errors proposed by Dulay et al. (1982) and sources of error from Richards (1974) were applied. The data were sentences on argumentative essay writing containing errors taken from final assignments of the third semester students of the English Education Study Program at Mahasaraswati Denpasar University. There are 25 data containing omission, 5 data containing addition, 35 data containing misformation, and 1 data containing misordering. Meanwhile, the sources of syntactic error that the researchers found are 12 errors caused by interlingual transfer and 33 caused by intralingual transfer.
\end{abstract}

Keywords: Syntactic Error, Verb Usage, Error Analysis

\section{Introduction}

There is no doubt that writing makes a great contribution to the world of literature and linguistics learning. In line with this, Brown (2004: 218) argues that writing skills have become indispensable and great importance in world of literature. Especially during the isolation of the covid-19 pandemic, writing becomes more important due to work from home (WFH) and remote learning. E-mail, papers, letters or documents on the Internet and other forms of writing is essential and being a basis of communication between remote teaching and learning in the present moment.

There are several numbers of English writing that should be mastered by the students; one of the notables is the argumentative text. Argumentative text recognizes its intrinsically social and dialogical nature, involves the presentation of a constellation of propositions intended to achieve the interlocutors' discursive goals (Ferretti \& Fan, 2016). Argumentative text may reveal the opinions of the natural phenomenon such as living or non-living things, and social phenomenon such as technology, economic issue, and political parties. Since argumentative text is a common text taught to students of English major, therefore it has been assumed that the students are familiar with it, in terms of the use of its grammatical features and generic structures. Yet, 
though the fact appears to be so, the errors in writing are still found in non-English speaking students' writing productions.

In learning target language, errors are common to happen. There are factors causing it, for instance that the target and the source language may have different language grammar, the lack of students' knowledge about target language structure, or misperception. But, in fact, the errors are often ignored by the teacher as the guide in learning. Therefore, the students don't have idea about the errors they make. They don't receive any feedbacks in their writing production, while it is essential for their writing skill. Error refers to the systematic errors of the learner from which are able to reconstruct his knowledge of the target language. It reflects a portion of the learner's competence in it. Thus, error cannot be self-corrected.

Corder in Richards (1974) claims that the making of errors is significant because it is part of the learning process itself. He also adds that the process of learning a second language is a fundamentally different nature from the process of primary acquisition. In order to get the uptake and feedback on their writing, it is needed to have a further analysis toward the errors' students make. Therefore, in order to analyze errors made by the learners, some experts in second language acquisition field then construct an approach namely, Error Analysis (EA). Gass \& Selinker (2008:103) define EA as a procedure for analyzing second language data that begins with the errors' learners make and then attempts to explain them.

Research on error analysis has been frequently done. Thus, it is important to take a view on former ones. Study from Hafiz et al. (2018) investigated the syntactic errors which Arabic speaking learners in Preparatory Year, Jazan University (Saudi Arabia) face in English writing. The results of their study reveal that the most common syntactic errors made by the learners are in sentence structure; subject verb agreement, tense, auxiliary verb, number, use of conjunction, preposition, article, etc.

Furthermore, Almahameed et al (2017) also committed to analyze the syntactic errors of 30 Jordanian EFL students at The Hashemite University. The results of their study displayed that syntactic errors produced by the participants were varied. Amongst syntactic errors, verb tense errors were the most frequent with $33 \%$. The results additionally revealed that two types of semantic errors were made; errors at sentence level and errors at word level. Errors at word level outstripped by far errors at sentence level, scoring respectively $82 \%$ and $18 \%$. It can be concluded that the students experienced syntactic errors and the frequent errors is in the type of verb tense.

Those previous researches took places in Middle East countries which known as non-English speaking countries just like Indonesia. Since the Indonesian language and English language have different language structure, thus the errors occur may differ in some ways as well. From those studies as well, it can be seen that the most errors students made in their writing were the usage of English verbs. Therefore, error analysis in the use of English verbs is very important to be investigated further. Besides, research on syntactical errors is immediately necessary to do in this local area for avoiding Indonesian students from making another error by going through the factors causing it.

Based on the necessity of doing an error analysis, this present study also aims to analyze the errors of the syntactic aspect in essay writing made by the third semester students of English Education Study Program at Mahasaraswati University. From the preliminary research conducted, there are also some errors found from the students' writing. For example, it is found that the student made a sentence "Some people think learn English is important". At glance, that sentence can be understood. However, if it is seen based on grammatical rules, it is wrong. Since the verb "think" has functioned as the main verb of the sentence, the verb "learn" in this case become the gerund. Gerund is a verb form which functions as a noun it can function as a subject or as an object. Therefore, the correct sentence should be "Some people think learning English is important", because learning English is the object of the verb "think".

This research answers its necessity by analyzing the syntactical errors in the use of verbs made by third semester students of English Education Study Program in Mahasaraswati University, in their English 
argumentative text writing. The students have been exposed to English language and structure since they were in the first semester. Since being the English education students, they require to be able to use English both in written and oral register, therefore they are expected that making error sentences is none of their problem any longer.

Considering the benefits of error analysis as a tool for improving students' language comprehension, this study intends to present a discussion about syntactic errors in applying the English verbs. Thus, this research aims at investigating whether the students make any syntactical errors. If any, the researcher intends to classify the type of errors and explain the source of errors as well. Additionally, error analysis is expected to give students some useful education improvements in the future to avoid causing other syntax errors in their writing.

\section{Theoretical Framework}

Every study should be supported by significant theories, proposed by some experts in the field of English learning. The theory of error types proposed by Dulay et al. (1982: 154-162) in their book entitled Language Two is applied to identify types of syntactic errors in the use of English verb form. The theory from Richards (1974: 5) about the source of errors in his book entitled Error Analysis: Perspective of Second Language Acquisition is used to analyze the causes of errors occurring from the learners based on the second problem. This research is also supported by the theory of English verb forms proposed by Parrott (2000: 93) in his book entitled Grammar for English Language Teachers, which describes the classification and uses of the English verb forms.

\subsection{Types of Errors}

Regarding the theoretical framework to the study of error analysis, first of all, errors should be identified and then they should be described. A number of categories are suggested for the error analysis. The categories developed in analyzing error made by the students consist of several alternatives for error classification. Dulay et al. (1982: 154-162) classifies the types errors into four different categories. The categories are: (1) omissions, (2) addition, (3) misformation, and (4) misordering. These categories provide a great deal of potential in defining cognitive mechanisms behind the reconstruction of the new language for learners. This also takes into account the mistakes of the students are not a function of laziness or slowness, but are based on certain logics due to interim concepts used by the learner in the development of a new language.

\subsection{Sources of Error}

In order to analyze the error which is made by the learner, it is important to make clear explanation about the error. In fact, errors are considered as the important mark of the language development in language learning. Richards (1974: 173) states that there are two sources of the learner's errors. They are the errors caused by the learner's native language and the structure of the English itself. The causes of error are categorized into interlingual factors and intralingual developmental factors.

\section{A. Interlingual Error}

Interlingual error or we usually called it as mother tongue interference. The interference of the learner's mother tongue is considered a major source of difficulty in the second language learning. If the structure of his mother tongue is different from the structure of the second language which is being learnt, this will, of course, make him commit an error (Richard, 1974: 94). These errors are the results of the learners' application 
of the native language elements to the target language. When encountered with new language, people tend to draw a connection between what they already know and what they do not. Learners carry over the knowledge of their native language to the performance of the target language. Here are some examples of error produced by Indonesian speaker:

\section{I happy}

Yesterday I ate dinner with my family

To know if there is an interlingual error and existence of similarity, the sentence in L2 translated into Indonesian as the L1. The first sentence indicates an interlingual errors in adjectival phrases; the learner interfered with L1 structure so that they produce I happy rather than I am happy because the translation in Indonesian shows the similarity; Saya bahagia which interferes learner's English sentence.

The second one, the error made by learner because they transfer their L1 structure into L2 structure. The translation of the L2 sentence is; kemarin Saya makan malam bersama keluarga saya. In Indonesian, the phrase makan malam is semantically and grammatically correct. Whether this phrase translated into L2 ate dinner is incorrect. English has its own idiomatic phrase for this utterance with have dinner/had dinner.

\section{B. Intralingual Error}

Intralingual transfer (error within the target language itself). This major of source has been recognized as the source of error which extend beyond interlingual errors in learning language. Intralingual refers to the items produced by the learners which do not reflect the structure of the mother tongue, but also generalization based on partial exposure to the target language (Richards, 1974: 174). These errors are referred to the errors that occur because of the ineffective traits of learning such as faulty application of rules and unawareness of the restrictions of rules. Richards (1974: 174) classifies the intralingual errors into four categories including over generalization, ignorance of rule restrictions, incomplete application of the rules, and false concept hypothesized.

a. Overgeneralization, covers instances where the learner creates a deviant structure on the basic of his experience of other structures in the target language (Richards, 1974:174). It happens when a learner creates a deviant structure on the basis of his experience of other structure in the target language. The example of forming plural by adding "s" to even irregular plurals, also generalizing the "-ed" past form. It typically entails the creation of one deviant structure in place of two target language structures, such as, he will works. The learner knows he talks, he smiles, and so on. It is, however, forbidden to use $-\mathrm{s}$ after the modal auxiliary. The students overgeneralize the rule of suffix $-\mathrm{s}$, which are only used after the third person in the simple present tense.

b. Ignorance of rule restrictions is the failure to observe the restriction of existing structure, which is the application of rules to the context where they do not apply (Richards 1974: 174). The learner of the second language does not obey the structure of the target language. In this type of error, the learner fails to observe the restrictions of existing structures. Some rule restriction errors may be accounted for in terms of analogy and may result from the role learning of rules. It entails applying rules in situations where they do not apply. They made me to go, for example, by extending the pattern found in the majority of verbs that accept infinitival complements. The learner disregards the use of make, which is not followed by to and a verb. The learner can add another sentence here, such as: They asked/wanted/invited me to go.

c. Incomplete application of the rules refers to the occurrence of the structure in which deviancy represents the degree of development of the rule required to produce acceptable utterances (Richards 1974: 177). This error may occur when learner fails to apply the rules completely due to the stimulus sentence. As a result, learners of L2 English have been observed to use declarative word order in the context in 
question, understand? In place of interrogative word order have you understood? or do you understand? This type of intralingual error is commonly referred to as a transitional competence error.

d. False concept hypothesized or fossilized; False concept hypothesized is kind of intralingual factor which have to do with faulty rule learning at various levels (Richards 1974:178). It is a class of developmental errors which is derived from faulty comprehension of distinction in the target language which is sometimes due to poor gradation of teaching items. Learners' faulty understanding of distinctions of target language items leads to false concept hypothesized. When a learner does not fully comprehend a distinction in the target language, this type of error occurs. For example, the use of was as a marker of past tense in one day it was happened. The form is may be understood to be the corresponding marker of the present tense; she is speaks English. In some narrative texts, the continuous form is used instead of the simple past: other places, there is confusion between too, so, and very, between come and go, and so on. These errors can occur as a result of poor gradation of teaching materials.

\section{Verbs Usage}

Verbs are sometimes called "action words". In addition, verbs can show many different types of actions. Parrott (2000: 93) describes many verbs as actions, the use of verbs to exist (e.g., to be), mental states and processes (e.g., trust, pleasure), relationships (e.g. depending on, determined) can also be used to denote other meanings. ). Parrot (2000: 93) also refers to several verbs such as: cry, cut, walk, listen, etc. Almost every sentence requires a verb. This is partly true. Many verbs give ideas for actions that are "what to do". So, in simple terms, a verb is a word that tells us what the subject does and does not do. Therefore, verbs are important in English grammar. You can include verb words in the sentence. But you can't make a sentence without a verb. The classification of English verb can be seen below.

\section{a. Main Verbs}

Parrot (2000: 94) states that the main verb conveys the key meaning of each group of verbs. For example, in the sentence You have finished your last project, the main verb is finished. The main verbs in English have certain forms which are as follows:

1. Infinitive

The infinitive is the simplest form of the verb. It is exactly the same as the 'base' form that follows I, you, we and they in the present simple tense of all verbs other than be (e.g., I drink, they believe), (Parrott, 2000: 170).

2. Present Tense

Parrott (2000: 188) adds in looking at the form of the present simple tense we need to make a distinction between verbs used with a third person singular subject (e.g., he, she, it, Barbara, a book) and verbs with other subjects (e.g., I, you, Lauren and Jack, the books). With other types of subjects, the form of present tense is the same as the infinitive form, however it has an inflection to and has an -(e)s inflection for third singular subject: e.g., She plants flowers, Barbara eats fruit.

3. Past Tense

Parrott (2000: 219) notes that the past simple is one of the tenses we use to refer to completed events, states or actions. We choose the past simple when we consider that the event, state or action took place within a finished period of time. We often use an expression such as last week, at the weekend, in 1972, 3 years ago, or when we were on holiday to make it clear that the period of time is finished. Sometimes, however, this completed period of time is only implied. The ending -ed on a verb shows that the event happened in the past.

In English there are two categories in the form of past tense which are as follows: The regular verbs for their past tense by adding an $-e d$ inflection: e.g., worked, copied, stopped. The irregular verbs typically form 
their past tense by an internal vowel change. Irregular verb is one that forms its past and past principle in some other way than a regular verb. Irregular verb forms their past and past participle in several ways: 1 . By changing a vowel. For Example: drink-drank-drunk. 2. By changing a vowel and consonant. For example: dodid-done. And 3. By making no change. For example: put-put-put.

4. Future

Parrott (2000: 200) states that some languages have a single 'future tense; whereas English uses a lot of different verb forms to refer to future time (e.g., will, going to, will be + -ing). It generally refers to this form as the going to future, and teach it as be+ going to+ bare infinitive. It is also logical to think of this as the present continuous form of go+ the full infinitive. Furthermore, the "will" forms use with the bare infinitive of the main verb.

\section{b. Auxiliary verbs}

There are two types of auxiliary verbs in English which are finite forms and non-infinite forms.

1. Modal Auxiliaries

Parrott (2000: 152) states that modal verbs belong to the larger category of auxiliary verbs, i.e., we don't use them on their own; we have to use them in conjunction with another (main) verb. They are thus sometimes also called 'modal auxiliaries'. English has a number of modal verbs which generally do not inflect, and so have only a single form, used as a finite verb with subjects of all persons and numbers. These verbs are can, could, may, might, shall, should, will, would, must, ought (to), as well as need and dare (when used with a bare infinitive), and in some analyses used (to) and had better. (The forms could, might, should and would are considered to be the past tenses of can, may, shall and will respectively, although they are not always used as such.) These verbs do not have infinitive, imperative or participle forms, although in some cases there exists a synonymous phrase that can be used to produce such forms, such as be able to in the case of can and could. The negation of can is the single word cannot. There are contracted forms ' $\mathrm{ll}$ and ' $\mathrm{d}$ for will and would (in some cases possibly considered to be from shall and should).

2. Auxiliary Have

In its role as an auxiliary verb, have can occur in either present or past tense. Have in present has two types depends on the subject. I, you, they, we use have. Besides, she, he, and it use has. Have in the past tense is had. It can be used for all of the subjects. Have can also act as an auxiliary verb or a main verb. If it is the rightmost verb in the verb phrase, it is a main verb; otherwise, it is an auxiliary verb.

3. Auxiliary be

In its role as an auxiliary verb, be can occur in either the present tense, past tense or past participle form. The verb form following auxiliary be is usually a present participle form: For example; We are giving our donations to the orphanage.

Like have, be can function as either an auxiliary verb or main verb. If it is the rightmost verb in the verb phrase, it is a main verb; otherwise, it is an auxiliary verb.

4. Auxiliary do

In its role as an auxiliary verb, do can occur in the present and past tense forms. Do in present has two types depends on the subject. I, you, they, we use do. Besides, she, he, and it use does. Do in the past tense is did. It can be used for all of the subjects. When auxiliary do occur in verb phrase, it appears as the first verb and will be present or past. The form of the following do is usually infinite (uninflected) form. 


\section{Research Methods}

The researchers focus on syntactic errors made by the third semester students of the English Education Study Program at Mahasaraswati Denpasar University. Therefore, the data in this research were taken from the essay writing made by 32 undergraduate students of English Education Study Program, in 3C class in the academic year of 2020/2021. Furthermore, the data from the interview with the students who committed errors were also be the primary data to answer the source of errors students had made. In order to find out and analyze the errors, the researchers apply Types of Errors theory from Dulay et al. (1982). The types of errors consist of omission, additions, misformation, and misordering. In addition, the Error Analysis theory from Richards (1974) is also applied to analyze how the students committed syntactic error.

The study which focuses on the data of English essay writing made by English Education Study Program students had been analyzed in order to find out the syntactic error types on the verbs' usage as well as the cause of the error committed by the students. The theory from Gass and Selinker's (2008:103) were applied to analyze the data gained. There are several steps of error analysis provided by Gas and Selinker, namely: (1) identifying errors, (2) classifying errors, and (3) analyzing errors.

1. Identify errors. Identifying the types of errors made e.g.: omission, addition, misformation, or misordering using theory proposed by Dulay et al. (1982).

2. Classify errors. Grouping the errors that have been found and stating the classes of the errors e.g.: error of verb tense, error of modal auxiliary, etc.

3. Analyze error. This step dealt with deeper analysis of the errors found and the sources of errors in the students' writing using the theory proposed by Richards (1974). The source of errors analyzed through relating the error with the theory about the causes of errors and confirmed by the result of the interview.

\section{Discussions}

\subsection{Types of Error}

Based on the data analysis, it can be concluded that from the students' argumentative essay writing, there are 66 errors which are classified into 7 omission of verb errors, 4 omissions of auxiliary verb: are errors, 14 omission of simple present tense marker: -s/-es. Furthermore, there are 5 addition errors found which are classified into 1 addition of to be: are error and 4 addition of simple present tense marker: $\mathrm{s}$ errors. There are a lot of misformation errors found in students' argumentative essay writing. It was found that there are 6 misformation of main verb errors, 15 misformation of auxiliary verb errors, 11 misformation of to be: is/are, was/were errors, and 3 misformation of modal verb errors. The last error is misordering; there is only 1 error found. The wrong place of subject-verb.

From the four types of error classified by Dulay et. al. (1982), the most dominant error made is misformation (35) and the least of the errors is misordering (1). Furthermore, the researchers elaborate some data for types of errors to be discussed below.

\section{A. Omission}

\section{[C-25] "Even though he had to ^ through many obstacles when he go ${ }^{\wedge}$ to his student ${ }^{\wedge}$ house."}

The incorrect sentence above is classified as an omission because the learner failed to present the required language items. (Dulay et al., 1982:154). This error is caused by the omission of main verb go after to. The correct English phrase should be to go through. Therefore, the correct sentence supposed to be "Eventhough he had to go through many obstacles when he goes to his students' house." 


\section{B. Addition}

\section{[C-19] "Learning face to face make^ the students and teachers are uncomfortable because they must use health protocol."}

The erroneous sentence above is classified into addition since the learner added unneeded language item (Dulay et al., 1982:156). This error is caused by addition of the unneeded auxiliary verb are. It was found that the error was double marking of to be after bare infinitive. The sentence was "Learning face to face make ${ }^{\wedge}$ the students and teachers are uncomfortable because they must use health protocol." Which is supposed to be "Learning face to face makes the students and teachers uncomfortable because they must use health protocol." Remove the are as the helping verb because there was a verb make as the main verb.

\section{Misformation}

[C-18] "By using this mobile classroom, the students will saving cost to buy some equipment for online

\section{learning"}

Misformation refers to the use of the wrong form of the lexical or structure, Dulay et al. (1982: 154-158). In this study, it was found that some students still did not know the rules of verb that follows the modal verb should be the infinitive. However, some of them still use the -ing form verb after the modal verb. Therefore,the correct sentence for above erroneous should be "By using this mobile classroom, the students will save cost to buy some equipment for online learning"

\section{Misordering}

\section{[C-19] "The virus would spread and expose the other students."}

Misordering items in constructions that require a reversal of word order rules, Dulay et al. (1982: 156-158). There is only one of misordering error found made by the student. The order should be Subject-Verb; however, the student made it into Verb-Subject order. Therefore, the correction for sentence above supposed to be "the virus would spread and the other students would be exposed to it." As the subject comes first before the verb.

\subsection{Syntactic Error}

12 interlingual errors were found on the use of verbs in the students' argumentative essay writing. It was found that interlingual error in omission of main and auxiliary verbs were mostly done by the students. The used of $\mathrm{L}_{1}$ rule in $\mathrm{L}_{2}$ sentence, the interference of Indonesian translation, and the used of Indonesian rule when making English sentence were the causes of students made errors on the usage of English verb. It was found that most of the error made by students was from intralingual transfer. It was found that 13 students made 33 of intralingual errors in total. It means that the students were failed to learn conditions under which rules apply. There were 21 intralingual error of overgeneralization, 5 intralingual error of ignorance of rules restriction, 4 intralingual error of incomplete application of rules, and 3 intralingual error of false concept of hypothesis.

From the two sources of error classified by Richards (1974), interlingual transfer (12) is the least while intralingual transfer (33) is the most frequently occurred. The dominant number of intralingual transfer (33) proves that the students failed to use the English verbs correctly. In other words, learners didn't have much knowledge of new language rules so they failed to use the correct form of the English verb used. 
A. Interlingual Error

[C-25] "Although he has to violate the rules set by the government which is should to work and study

$$
\text { from home." }
$$

These errors are the results of the learners' application of the native language elements to the target language, Richards (1974: 94). The student number C-25 put should to in her sentence for should to work. Whereas, modal verb should cannot be followed by to. The incorrect verb used was the interference of Indonesian translation; diharuskan untuk bekerja dan belajar dari rumah. Therefore, the correct sentence has to be "Even though they have to violate the rules set by the government, that is, they have to work and learn from home."

\section{B. Intralingual Error}

Intralingual refers to the items produced by the learners which do not reflect the structure of the mother tongue, but also generalization based on partial exposure to the target language (Richards, 1974: 174). Student number [C-5] overgeneralized the use of bare infinitive for first person singular and third person singular in simple present tense. In her writing found that verbs usage for third singular pronoun were the same as the first singular pronoun. For example, in her sentence for example:

\section{The teacher help ${ }^{\wedge}$ the student to learn}

The sentence supposed to be:

The teacher helps the student to learn

Third person singular present indicative form with the suffix -[e]s. It is formed in most cases by adding -s to the verb's base form: help $\rightarrow$ helps.

It also found that some students made the same error. The overgeneralization of bare infinitive for third person singular present. One sentence for example:

He teach^ the students using pedals mobile school in this pandemic situation

The sentence supposed to be:

He teaches the students using pedals mobile school in this pandemic

Third person singular present indicative form with the suffix -[e]s. It is formed in the sentence above by adding -es to the verb's base form ends in one of the sibilant sounds $(/ \mathrm{s} /, / \mathrm{z} /, / \mathrm{J} /, / 3 /, / \mathrm{t} /, / \mathrm{d} 3 /)$ and its spelling does not end in a silent e, then -es is added: teach $\rightarrow$ teaches.

\section{Conclusion}

Students make errors in different types and numbers. Among the four types of error classified by Dulay et al. (1982), the most dominant error made is misformation (35) and the least of the errors is misordering (1). From the two sources of error classified by Richards (1974), interlingual transfer (12) is the least while intralingual transfer (33) is the most. The dominant number of intralingual transfer (33) proves that the students fail to use the English verbrules correctly. In other words, learners don't have much knowledge of target language rules so the learners fail to use the correct form of the English verb used. 


\section{References}

Almahameed, Y.S., Shaikhli, M. A. (2017). Understanding Syntactic and Semantic Errors in the Composition Writing of Jordanian EFL Learners. International Journal of Applied Linguistics \& English Literature (Online) Vol. 6 No. 6; Australian International Academic Centre: Australia.

Dulay, et al. (1982). Language Two. New York: Oxford University Press.

Ferretti, R. P., \& Fan, Y. (2016). Argumentative Writing. In C. A. MacArthur, S. Graham, \& J. Fitzgerald (Eds.), Handbook of writing research (2nd ed., pp. 301-315). New York: Guilford Press.

Gass M, Selinker L. (2008). Second language Acquisition. An Introductory Course.

Third edition. Mahwah, N.J.: Lawrence Erlbaum Associates.

Hafiz, M. S., Omar, A. M. A., Gul Sher, K. R. M. (2018). Analysis of Syntactic Errors in English Writing: A Case Study of Jazan University Preparatory Year Students. Journal of Education and Practice. Vol.9, No.11.

Parrott, Martin. (2000). Grammar for English Language Teacher. Cambridge: Cambridge University Press.

Richards, Jack, C. (1974). Error Analysis: Perspective on Second Language Acquisition. London: Longman. 